\title{
The Practice of English Reading Teaching in Junior Middle School based on Basic Education Reform
}

\author{
Ping $\mathrm{SHI}^{1 \mathrm{a}}$, Wei WANG ${ }^{2 b}$ \\ ${ }^{1}$ Tianjin University of Technology, China \\ a1063734555@qq.com, b763845448@qq.com
}

Keywords: The reform of basic English education; Basic English Teaching; Educational thinking

\begin{abstract}
The reform of basic English education has constantly infiltrated into the aspects of teaching, and English reading teaching is no exception. As an important component of the English Curriculum of basic education, teaching requires students to master some basic knowledge of English both written and oral English reading ability, form the basic comprehensive language ability, cultivate students' observation, memory, thinking, imagination and innovation spirit. As a universal language in the world, English is an important medium for modern daily work to obtain information resources. Therefore, the improvement of English reading ability has become an important work in the current English teaching. However, due to the influence of traditional methods, the current English Reading Teaching in China still faces some problems and difficulties, the overall level of English education and enhance the social influence on English reading needs, this article from the current status of junior high school English reading teaching, tries to analyze the related countermeasures to improve junior high school English reading teaching.
\end{abstract}

\section{Introduction}

With the development of the information age and the increasing frequency of communication between countries, English has become an important language of the international community and even international conferences. In the field of our research, English is also used as the main language of periodicals. Therefore, with the extensive application of English, more and more countries are beginning to strengthen and develop English teaching reform at the basic education stage. At present, in the process of school learning, there is still a low efficiency problem, even in the process of teaching, such as many English teaching workers. Junior high school is the basic stage of English learning, and it is also an important period for the rapid improvement of students' language ability. In the learning stage of junior middle school in China, the traditional thinking has always existed in the classroom teaching, and English learning is no exception. Reading ability is a kind of comprehensive ability. It is a comprehensive application of the students' ability to learn words, grammar, sentence patterns and so on. The level of English reading in junior middle school is related to the overall English level of students. It plays a decisive role in the comprehensive use of English in future work. Therefore, it is necessary for us to discuss the teaching of English reading in junior middle school. 


\section{The present situation of English reading teaching in junior middle school}

Reading can be divided into two stages. From the perceptual stage of identifying character symbols, we can sublimate to understand the content, absorb information, and understand the stage of rational thinking of creative thinking decoding. Correspondingly, the cultivation of reading ability should include two different reading abilities. One is the reading ability of language knowledge points, which is the basis of communicative reading level; the two is communicative reading ability, which is the improvement of language knowledge reading level. At present, the common phenomenon in junior high school English teaching is that reading ability is basically stopped above the reading ability of language knowledge. Teachers and students spend a lot of time and energy in analyzing and understanding words and grammatical knowledge, but they don't attach importance to the cultivation of information and communicative level of reading. Students are hard to form accurate and smooth reading skills, thus impeding the improvement of reading ability. In order to correct this tendency, a large number of Communicative Reading Training should be carried out.

The traditional junior middle school English reading teaching is universal, which is more than two ways. One is to rely on Teachers' explanation or to increase courseware playback on the basis of explanation. The two is to teach phrases and grammar knowledge points by word and sentence, and students to mark notes on books. Although the two methods may be the most direct and effective way to cope with the examination of teachers and students, but this method has disadvantages cannot be ignored, the students in this environment and gradually develop a dependence on teachers, not formed their own effective reading skills, do not know how to read and understand the whole the deep meaning, cannot understand the low reading ability, reading effect.

\section{Different modes of school education between China and the United States}

Both China and the United States have great differences in the educational system, the educational model, and the content of education. First, there are differences in the educational system. What China pays attention to is the traditional education and teaching model, and it can also be attributed to paternalistic education. In the United States, the emphasis is on open teaching, they lead the students to form liberalism values at the core of individualism so as to achieve an open education and teaching model. Secondly, in the ways and methods of school education, There is a distinct difference between China and the United States restricted by the system of examination oriented education in China, school education is realized mainly through the way of instillation of Ideological and political theory. To strengthen students' memorizing ability of knowledge points, the curriculum standards, teaching materials and teaching plans of these courses are basically unified. While the United States pays attention to the implicit infiltration education. Schools at all levels in the United States have formulated corresponding educational rules in accordance with the requirements of the social development in the region. Integrate the content of education into geography, history, sociology and so on. Final, the characteristic of American school education lies in the "service learning" formed by the combination of community service, Students continue to enhance their learning skills by participating in social activities. 


\title{
Countermeasures to improve the teaching of English reading in junior middle school
}

\author{
Pay attention to psychological factors
}

Many teachers and students believe that to understand the words and grammar, you can master the reading text, and the ability to read naturally. In fact, reading is a psychological activity with rich connotation. It contains psychological activities such as perception, understanding, analysis, synthesis, memory, association, judgement, reasoning and so on. If we attach importance to psychological factors, we can bring a lot of teaching results.

We should change the traditional understanding of reading. This includes two aspects of teachers and students. From a teacher's perspective, teachers worry that reading will increase student burden and affect teaching plan. In fact, we should pay attention to the promotion of reading teaching to the whole teaching. From a student's perspective, many students are afraid of reading. Especially when students read new words in reading, they are more resistant to ideas than they think they can understand. Therefore, teachers must take some means of psychological intervention to encourage and influence students to read, and try to enhance their confidence in reading. At the same time, teachers should teach students in accordance with their aptitude, arrange students' age and level, arrange step by step, set up a reasonable plan, do not blindly go to the horse, and make mandatory orders, which will only backfire and cause students' rebellious feelings.

\section{Cultivate students 'reading skills}

First of all, it is necessary to introduce reading skills systematically and step by step. For example: the exclusion of non key words and context guessing, find the key words, sentences, reading frame center. After teaching students' reading skills, let students try them in person, and gradually establish their reading confidence so that they can understand that they do not understand all the new words to read the whole article, and that appropriate reading skills can also understand the meaning of the article. After the fear of the students, reading ability and speed will be improved. Reading comprehension and speed are the most important basic skills training. Only the understanding of the things can be kept in mind, only the value of migration can be used in the future. The improvement of reading speed depends on the improvement of understanding, and the improvement of understanding depends on a lot of reading practice, which depends on the speed of reading.

Meanwhile, we should improve reading habits. Some students must read quietly before finishing reading. Practice has proved that this habit is not conducive to the improvement of reading speed. Therefore, controlling oral action and silent learning to complete reading comprehension process has become an important aspect. Try to control eye saccades, body sway back and forth and other bad habits in reading, form a good habit of reading, not only help to improve the reading efficiency, more conducive to the overall comprehension ability. The eyes are the windows of the soul, through the visual information is the most effective means for expanding the horizon, but also enhance the reading speed, reading ability, proper reading practice training is very necessary.

\section{Conclusion}

English reading ability occupies a very important position in English learning. Stimulate students' interest in reading as a basis for improving students' English ability, and develop a good learning attitude. It enables students to acquire knowledge and experience the pleasure 
of reading in English, so as to improve their English reading level. In the English teaching mode, we should change the single teaching method, focus on students' interest, enrich teaching contents and pay attention to students' emotional expression. At the same time, we should improve students' self-confidence, develop good habits, and actively overcome difficulties in English learning.

Junior middle school is the basic stage of learning English, English reading teaching is an important part of the junior high school English, English ability is more and more valued by the society, English reading ability is directly related to the level of students' learning, all aspects of the work, therefore, must pay attention to English reading teaching in junior high school, trying to improve students' English reading ability. Teachers should strengthen the teaching of English reading from many fields of thought and practice, and stimulate students' interest in English reading and learning. English reading teaching also needs long-term and systematic practice, and may also encounter setbacks. It also needs to be persistent and continuous to draw lessons from it, so as to improve students' English reading ability and promote the continuous progress of basic education reform.

\section{References}

[1] Li Jun, the reflection and exploration of English Reading Teaching in high school under the new curriculum standard, Neijiang science and technology, 2006 (8): 153.

[2] Pijun LIU, educational psychology [M], Shanghai: China Economic Press, 2010.

[3] Weiyu CHEN, the problems and time strategies for the teaching of long reading in junior middle school [J], foreign language teaching in primary and secondary schools, 2009 (10)

[4] Zhang. Application of task-based reading in junior middle school English reading teaching [D]. Huazhong Normal University, 2013.

[5] Wang Yan. Junior middle school English reading teaching problems and Countermeasures [D]. Liaoning Normal University, 2011.

[6] Fu Ye. Main problems and Countermeasures in junior middle school English reading teaching [D]. Northeast Normal University,2015 